\title{
Self-Healing Properties of Steel Slag Bio Concrete
}

\author{
Dr.V.Subathra Devi \\ Associate Professor, Saveetha Engineering College, Chennai \\ subidevi@gmail.com
}

\begin{abstract}
The building with crack has all the power to spoil the strength and aesthetic view and it may also lead to collapse. Crack lets in the moisture and hence the permeability increases in concrete which results in corrosion of reinforcement. As a result the tensile strength and compressive strength of the building will get reduced considerably. In this research, steel slag is used as a replacement material for fine and coarse aggregate, after comparing the properties of steel slag with the standard conventional material from 0 to $50 \%$ in steps of $10 \%$. By inculcating bacteria in the optimum replaced steel slag concrete, in various quantities of $10 \mathrm{ml}, 20 \mathrm{ml}$ and $30 \mathrm{ml}$, UPV (ultrasonic pulse velocity) test is conducted after 28 days of curing. The bacterium used is Bacillus subtilis, which is a gram positive cell bacterium. The increase in compressive, tensile and flexural strength of SSBC (Steel Slag Bacterial Concrete) is observed than the $\mathrm{CC}$ (conventional concrete) of M20 grade. No flaws are deducted in SSBC. The performance characteristics of steel slag concrete can be improved by Bacillus subtilis bacterium which can be easily cultured and safely used and moreover self healing of cracks can be made.
\end{abstract}

Keywords-Bacillus subtilis, Bacterial concrete, Compressive strength, Steel slag, Self healing.

\section{INTRODUCTION}

Even today in modern technology, skyscrapers and large structures are constructed using conventional concrete. Use of conventional concrete, will limit the load impact on the structures wherein skyscrapers or large structures are expected to experience more loads than they are actually designed for. The remains of the steel after manufacturing process are called steel slag. Steel slag proves to be harmful to environment when not treated properly. But, it also helps in increasing the compressive strength when added in a limited percentage. Generally, aggregates are replaced by steel slag from 0 to $50 \%$. Bacteria are introduced in the optimum replaced steel slag concrete. During aging of building, the cracks occurred is self healed by the bacteria. The bacteria react with the chemical and precipitates calcite which blocks the entry of moisture and foreign particles into the structure. Due to this process, the strength of the structure is maintained and hence age of building is increased. In this research, steel slag \&bacteria bacillus subtilis along with formaldehyde is used. Bacillus subtilis is used since it proves no harm to man and environment.
In order to protect the environment, Pozzolanic material can be used as partial substitute up to $30 \%$ in the production of blended cement. Due to this addition $\mathrm{CO}_{2}$ release to the environment can be reduced [1]. When palm kernel shell is used as a replacement for aggregate, there is decrease in workability and strength of the concrete and also it increases the water absorption. Implementing the sustainable material in Construction is becoming fast and good [2]. The biological wastes such as eggshell and palm oil fuel ash can be used as hybrid biofillers in concrete mixture as an alternative to Portland cement [3].Without direct human guidance, ordered structures are possible. The soft and flexible materials organize structures of hard and rigid structures [4]. In low-temperature marine environments, bacterial based bead can be used for self healing purpose. The bead which is made of calcium alginate encapsulated bacterial spores and mineral precursor compounds is a biocomposite healing material, which makes the concrete to heal on itself [5]. Micro capsules made of sodium silicate solution with complex coacervation, when embedded in cement mortar, behaves soft and rubbery when hydrated, and when dry transits to stiff and glassy material. Micro capsules are very stable in strong alkaline solution. The microcapsules survive in mixing and release their cargo upon fracture [6]. For the treatment of aged concrete structures, bacteria-based repair mortar and liquid systems are developed [7]. Self healing agent is alive for about 200 years but will not actively grow with in the concrete. Calcium concentration, Concentration of dissolved inorganic carbon, the $\mathrm{pH}$ and the availability of nucleation sites are the key factors in the process of calcium carbonate precipitation to remediate cracks in concrete. Bacteria are broadly classified based on shape, gram stain and oxygen demand [8]. Some bacteria like bacillus Sphaericus, bacillus pasteurii, bacillus subtilis, and bacillus flexus does not impose any bad effect on human health and also shows higher ability of calcite precipitation. Water absorption of the concrete will get reduced by around $50 \%$. The cost of bacterial concrete will increase around $30 \%$ than the conventional, but that can be compensated with the least maintenance cost [9]. The selection of bacteria is according to their survival in alkaline environment. For the growth of bacteria, they are put in different chemical, temperature and time period. Bacteria improves the structural and durability properties. Self healing properties of concrete can be achieved when 
light weight aggregates are used along with bacteria [10]. Bacillus subtilis SPB1 lipopeptides can be potentially used in toothpaste due to its physicochemical parameters, antibacterial activity and its stability [11]. When diatomite pellets are used as coarse aggregate in bacterial concrete, positive effects are observed in compressive strength [12]. Cement can be replaced partially by some eco-friendly alternative materials and by means of increasing the life time of concrete, it can be made as a sustainable material. Inspecting concrete for cracks then and there is costlier and time consuming. Concrete degrades when micro cracks originates, grows gradually and leads to corrosion of reinforcement. When bacteria are incorporated in spore state and when water penetrates, it awakens the bacteria, which in turn oxidizes calcium lactate to form calcite. Insoluble calcium carbonate precipitates on the surface and hence the cracks are filled, making the concrete more durable with less permeability. Bioconcrete can increase the life of structure by 50 years more. The places where maintenance is difficult and expensive, bioconcrete can be used [13]. Calcium carbonate formation mediated with bacteria results in physical closure of micro cracks [14]. The biosurfactants produced by the microbial species bacillus subtilis, enhance the degradation process of polyethylene. The weight loss in polyethylene is around $9.26 \%$ in a period of one month [15]. Bacillus subtilis is safe, without any undesirable physiological effects on liver and kidney function, blood count and hemodynamic parameters [16]. The drawbacks in using bacteria into the concrete are Cost of bacterial concrete is double, bacterial growth in atmosphere, bacterial concrete mix design is unavailable, Investigation of calcite-precipitation study is costly[17].

\section{EXPERIMENTAL DETAIL}

\section{Material Cement}

Cement is a binding material used in the preparation of concrete. It binds in the coarse aggregate and fine aggregate with the help of water, to a monolithic one and also it fills the fine voids in the concrete. Cement that we have used in this research is Portland Pozzolano cement of grade 53, Chettinad Cement. The properties of cement such as Initial and Final setting time, Fineness and standard Consistency are tested and given in table.
TABLE . 1 PHYSICAL PROPERTIES OF CEMENT

\begin{tabular}{|l|c|c|c|}
\hline \multicolumn{1}{|c|}{ Properties } & River sand & Steel slag & $\begin{array}{c}\text { Standard value } \\
\text { (IS 383-1970) }\end{array}$ \\
\hline Voids in sand (\%) & 41.2 & 56.0 & - \\
\hline Specific gravity & 2.6 & 3.3 & $2.5-2.7$ \\
\hline Water absorption (\%) & 1.0 & 1.3 & $0.1-2.0$ \\
\hline
\end{tabular}

\section{Aggregates}

River sand is used as fine aggregate. Rock when crushed in to fine grains, product resulting from erosion of siliceous material results in a loose granular substance with mineral particles. Based upon the origin, the composition of sand is varies. Crushed stone of $20 \mathrm{~mm}$ size and angular shape is used as coarse aggregate.

\section{Steel slag}

Steel slag, is a product left over when the steel metal is extracted from its ore. Steel slag is a mixture of metal oxides, metal sulphides, silicon dioxide. Based on the furnaces from which they are generated, slag is named. Slag is a complex solution of silicates and oxides that solidifies upon cooling. The steel slag used in this research work was obtained from the open stocking yard of Agni Steels Private Limited, Ingur, Erode, Tamilnadu, India where steel slag was stockpiled over a period of 1.5 years. The properties of steel slag are compared with the natural aggregates as shown in table.

TABLE 2.PROPERTIES OF STEEL SLAG WITH NATURAL FINE AGGREGATE

\begin{tabular}{|l|l|l|}
\hline Test particulars & Results & $\begin{array}{l}\text { Requirement as } \\
\text { per IS:12269- } \\
\mathbf{1 9 8 7}\end{array}$ \\
\hline Specific gravity & 3.15 & --- \\
\hline Fineness $\left(\mathrm{m}^{2} / \mathrm{kg}\right)$ & 300 & $225(\mathrm{Min})$ \\
\hline Initial setting time (min) & 45 & $30($ Min) \\
\hline Final setting time (min) & 300 & $600(\mathrm{Max})$ \\
\hline Soundness (mm) & 1 & $10(\mathrm{Max})$ \\
\hline Standard consistency (\%) & 29 & -- \\
\hline
\end{tabular}


TABLE 3

PROPERTIES OF STEEL SLAG WITH NATURAL COARSE AGGREGATE

\begin{tabular}{|l|c|c|c|}
\hline \multicolumn{1}{|c|}{ Properties } & Gravel & Steel slag & Standard values \\
\hline Impact $\mathrm{J} / \mathrm{m}^{2}$ & 9.0 & 25.3 & $<45$ \\
\hline Crushing $\mathrm{N} / \mathrm{mm}^{2}$ & 36.5 & 62.0 & $<45$ \\
\hline Attrition (\%) & 5.4 & 4.1 & $<2$ \\
\hline Specific gravity & 2.8 & 3.8 & $2.5-2.7$ \\
\hline Water absorption (\%) & 0.5 & 5 & $0.1-2.0$ \\
\hline
\end{tabular}

\section{Bacteria}

Bacillus Subtilis, the best harmless bacteria usually found in soil and intestinal track of human, can tolerate extreme environmental conditions. It is a dormant bacteria, which is alive and not actively growing, temporarily inactive, when needed it heals the cracks.
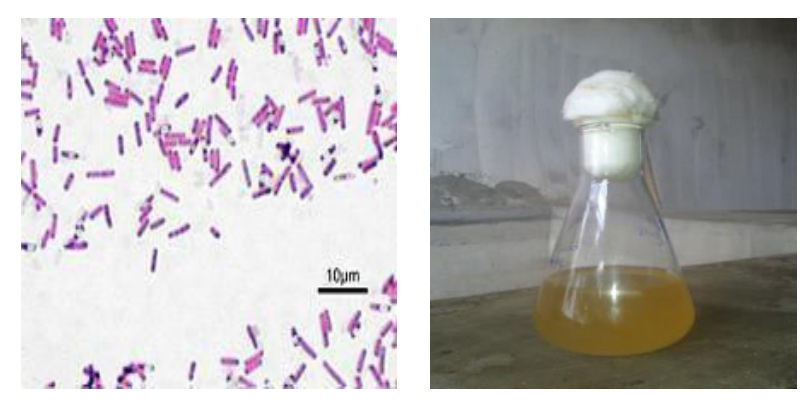

Figure 1 (a) Bacillus Subtilis (b) Cultured bacteria

The nutrient agar medium is used to culture the bacteria, which forms the irregular white colonies. Whenever required a single colony of the culture is inoculated into nutrient both of $200 \mathrm{ml}$ in $500 \mathrm{ml}$ conical flask and the growth conditions are maintained at 37 degree temperature and placed in $125 \mathrm{rpm}$ orbital shaker. The medium composition required for growth of culture is Peptone, Sodium Chloride $(\mathrm{NaCl})$, yeast extract, which is shown in figure .The cultured bacteria is added to fresh concrete at 37 degree Celsius and for safe later stage usage it should be refrigerated at $4^{\circ}$ Celsius.

\section{Mix design}

The mix proportion required for the experimental work is designed as per the Indian Standard code with the minimum cement content prescribed. Design is made using the properties of materials found experimentally for the cement, fine aggregate and coarse aggregate. The mix is designed for M20 grade of concrete by IS10262- 1982, using Portland Pozzolana Cement (PPC) 53 grade cement,
$20 \mathrm{~mm}$ size coarse aggregate with river sand passing through $4.75 \mathrm{~mm}$ sieve. The minimum cement content adopted for mix design is $383 \mathrm{~kg} / \mathrm{m}^{3}$. The specific gravity and water absorption of various ingredients of concrete are used in design. The target mean strength for mix proportioning is $27.6 \mathrm{~N} / \mathrm{mm}^{2}$. The mix ratio obtained is 1:1.81:3.93 with water cement ratio (W/C) 0.5 .

\section{Specimen details}

The shape and size of the specimens for various tests used in this research work are as per IS code recommendations. Cube specimen of size $150 \mathrm{~mm} \times 150 \mathrm{~mm} \times 150 \mathrm{~mm}$ is used for compressive strength test, UPV conforming to IS:10086-1982. Cylinder of size $300 \mathrm{~mm} \mathrm{x} 150 \mathrm{~mm}$ diameter is used for Split Tensile Strength test. Beam of size $500 \mathrm{~mm} \times 100 \mathrm{~mm} \times 100 \mathrm{~mm}$ is used for flexural strength test.

\section{Methodology}

Conventional concrete (CC) with mix ratio 1:1.81:3.93 with W/C ratio 0.5 is used without any replacement of cement and conventional aggregates. Steel slag concrete (SSC) is the one in which fine aggregate is replaced by fine steel slag and coarse aggregate by coarse steel slag from $0 \%$ to $50 \%$ insteps of $10 \%$. The optimum percentage of replacement is taken for bacterial inclusion. Steel slag bio concrete (SSBC) is made in three combinations by including bacteria in various quantities such as $10 \mathrm{ml}, 20 \mathrm{ml}$, $30 \mathrm{ml}$. Specimens were cast for different proportions and its fresh ad hardened concrete properties were studied.

\section{RESULT AND DISCUSSION}

\section{A. Optimum percentage of replacement}

For the SSC at 28 days, the compressive strength of the concrete increases up to $40 \%$ and $30 \%$ for fine and coarse aggregate replacement by steel slag respectively and after which it decreases. Therefore, this $40 \%$ and $30 \%$ is taken as the optimum percentage of replacement for fine and coarse aggregate by steel slag respectively.

\section{B. Fresh Concrete Properties}

To measure the workability of concrete, slump test is made, which gives the consistency of the fresh mix, when conventional aggregates are replaced by steel slag and bacterium is added. The slump value increases as the replacement by steel slag and bacteria increases. The slump values of various types of concrete were shown in table 3.1. This shows that it's easy to work with when replacement is made by steel slag and bacterium. 
TABLE 4

\section{SLUMP OF VARIOUS TYPES OF CONCRETE}

\begin{tabular}{|c|c|c|c|c|c|}
\hline \multirow{2}{*}{$\begin{array}{c}\text { CC } \\
(\mathrm{cm})\end{array}$} & \multirow{2}{*}{$\begin{array}{l}\text { SSC } \\
(\mathrm{cm})\end{array}$} & \multicolumn{3}{|c|}{ SSBC } & \multirow{2}{*}{$\begin{array}{c}\text { Recommended } \\
\text { Value }\end{array}$} \\
\cline { 3 - 5 } & & $10 \mathrm{ml}$ & $20 \mathrm{ml}$ & $30 \mathrm{ml}$ & \\
\hline 45 & 49 & 51 & 53 & 54 & 40 to $60 \mathrm{~cm}$ \\
\hline
\end{tabular}

\section{Hardened Concrete Properties}

\section{Compressive Strength}

As the concrete is strong in compression and weak in tension, it's vital to compare the compressive strength of the replaced concrete with that of conventional one. The procedure is executed as per the IS 516- 1959, using the universal testing machine. Compressive strength is influenced by the mix design ratios of water cement, aggregate cement, grading, texture, size etc. Cubes of size $150 \mathrm{~mm} \times 150 \mathrm{~mm} \times 150 \mathrm{~mm}$ were tested for each trial mix combination at the age of 7 and 28 days of curing. The value indicated in the figure 3.1 is the average of three measurements. The compressive strength of concrete increases gradually, as the percentage of replacement by steel slag increases up to the optimum of $40 \%$ Fine aggregate replacement and $30 \%$ coarse aggregate replacement. When the cultured bacterium is added to steel slag concrete, the compressive strength increases on a large scale of $41 \%$.

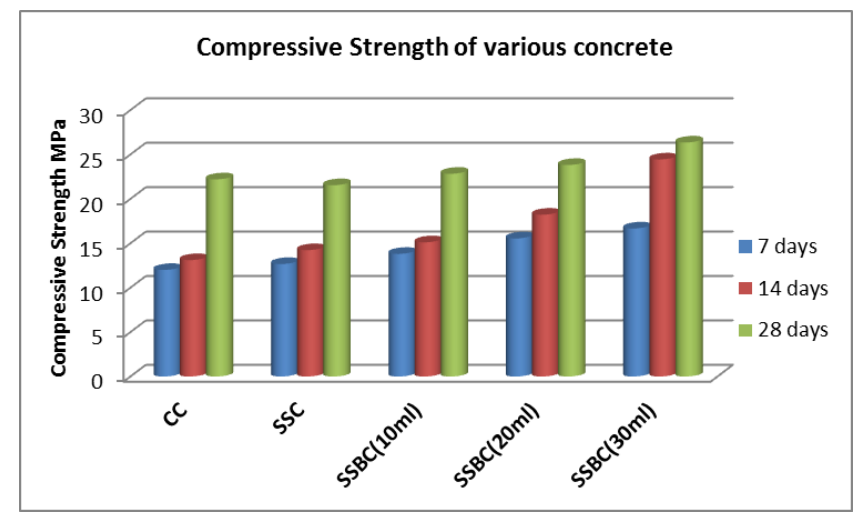

Figure 2Compressive Strength of various concrete

\section{Tensile Strength}

To determine the tensile strength of concrete, indirect test of splitting tension is performed. Split tensile strength was determined in accordance with IS: 5816-1970. The cylindrical specimens of size $150 \mathrm{~mm}$ diameter and 300 $\mathrm{mm}$ height are used to measure the tensile strength. The tensile strength at 7, 14 and 28 days of all the designated mix is shown in figure. As the percentage of replacement of steel slag increases the tensile strength increases on a maximum of $21.6 \%$. When cultured bacteria is added to the steel slag concrete, the increase in tensile strength is about $30.2 \%$. This is because of the surface texture and aggregate particle size embedded in concrete, and the bacteria, which provides better adhesion to the cement paste.

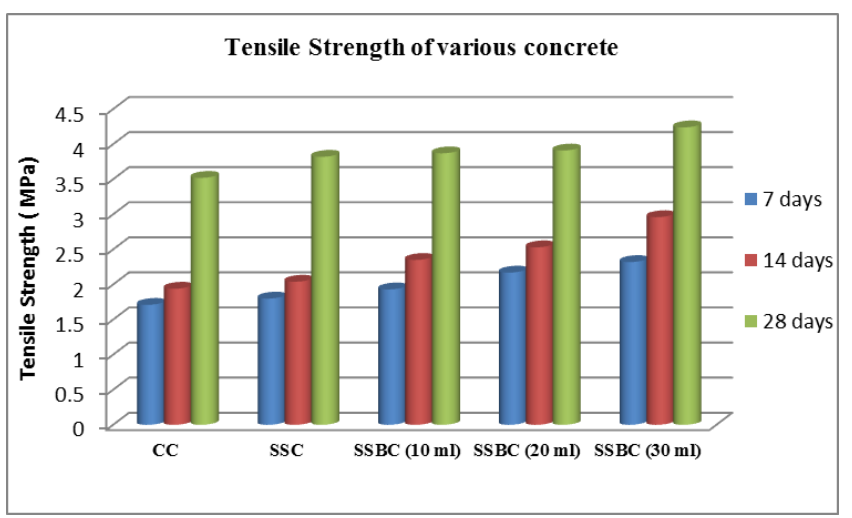

Figure 3 Tensile strength of various concrete

\section{Flexural Strength}

Flexural strength is measured to find the amount of resistant offered by the unreinforced concrete specimen, when subjected to pure bending. The flexural tensile strength at failure is shown in figure 3.3. In accordance with IS: 516-1959, flexural strength of concrete was measured using prism of size $500 \mathrm{~mm}$ x $100 \mathrm{~mm}$ x 100 $\mathrm{mm}$. In the bed of testing machine, two steel rollers of 38 $\mathrm{mm}$ diameter was provided at $40 \mathrm{~mm}$ centre to centre, to achieve symmetrical two point loading.

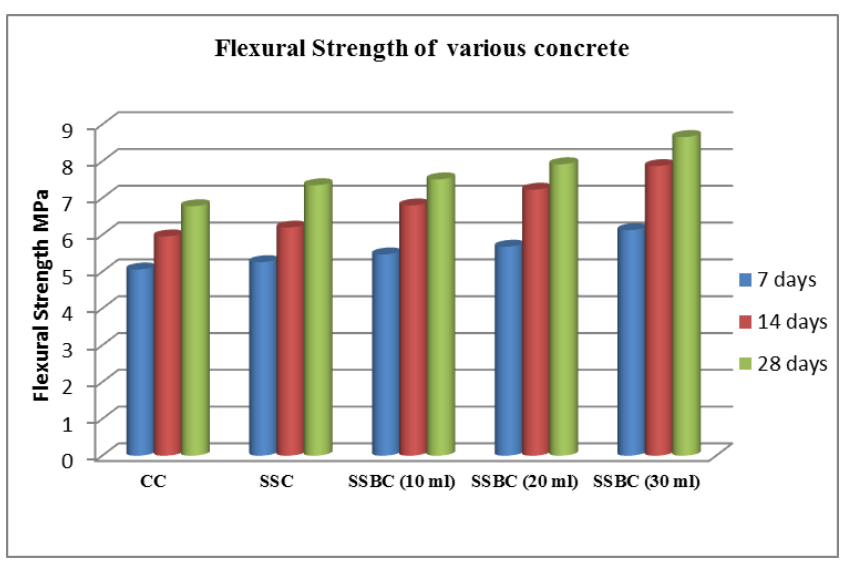

Figure 4 Flexural strength of various concrete 


\section{Ultrasonic Pulse velocity}

A non-destructive test to assess the quality of concrete is ultrasonic pulse velocity test. The test is done as per IS: 13311 (Part 1) - 1992 and the equipment is shown in figure 3.4. An ultrasonic pulse is passed through the hardened concrete to be tested and its time of travel is measured. When concrete is of good quality in terms of density, uniformity and homogeneity, higher velocity should be obtained. The value in the table shows as the bacteria is added in $30 \mathrm{ml}$, the velocity is higher than the other designated mix. This shows that at later stages, the CSH gel formation is more, making the steel slag concrete more denser, without any flaws in them. This is clearly shown in figure, which is visible to the naked eye.

\section{TABLE 5 VELOCITY OF ULTRASONIC WAVE PASSING THROUGH VARIOUS CONCRETES}

\begin{tabular}{|c|c|c|c|c|c|}
\hline \multicolumn{2}{|c|}{ Designation } & Days & $\begin{array}{l}\text { Distance } \\
(\mathrm{mm})\end{array}$ & Time (Sec) & $\begin{array}{l}\text { Velocity } \\
\text { (mm/sec) }\end{array}$ \\
\hline \multirow{3}{*}{\multicolumn{2}{|c|}{$\mathrm{CC}$}} & 7 & 150 & 35.3 & 4.3 \\
\hline & & 14 & 150 & 34.8 & 4.3 \\
\hline & & 28 & 150 & 34.1 & 4.4 \\
\hline \multirow{3}{*}{\multicolumn{2}{|c|}{ SSC }} & 7 & 150 & 33.6 & 4.5 \\
\hline & & 14 & 150 & 33.1 & 4.5 \\
\hline & & 28 & 150 & 32.7 & 4.6 \\
\hline \multirow{9}{*}{$\begin{array}{l}\text { SS } \\
\text { BC }\end{array}$} & $10 \mathrm{ml}$ & \multirow{3}{*}{7} & 150 & 32.8 & 4.6 \\
\hline & $20 \mathrm{ml}$ & & 150 & 32.5 & 4.6 \\
\hline & $30 \mathrm{ml}$ & & 150 & 31.9 & 4.7 \\
\hline & $10 \mathrm{ml}$ & \multirow{3}{*}{14} & 150 & 32.1 & 4.7 \\
\hline & $20 \mathrm{ml}$ & & 150 & 31.5 & 4.8 \\
\hline & $30 \mathrm{ml}$ & & 150 & 31.1 & 4.8 \\
\hline & $10 \mathrm{ml}$ & \multirow{3}{*}{28} & 150 & 31.1 & 4.8 \\
\hline & $20 \mathrm{ml}$ & & 150 & 30.7 & 4.9 \\
\hline & $30 \mathrm{ml}$ & & 150 & 29.5 & 5.0 \\
\hline
\end{tabular}
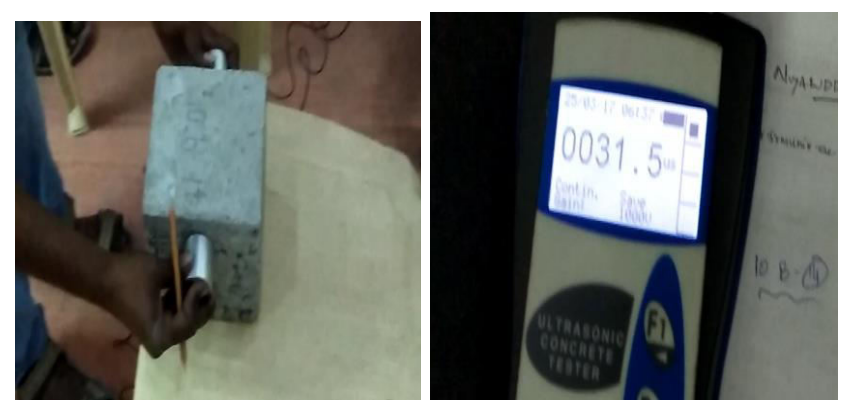

Figure 6 (a) Wave transmission and receiving (b) Time taken by the ultrasonic wave
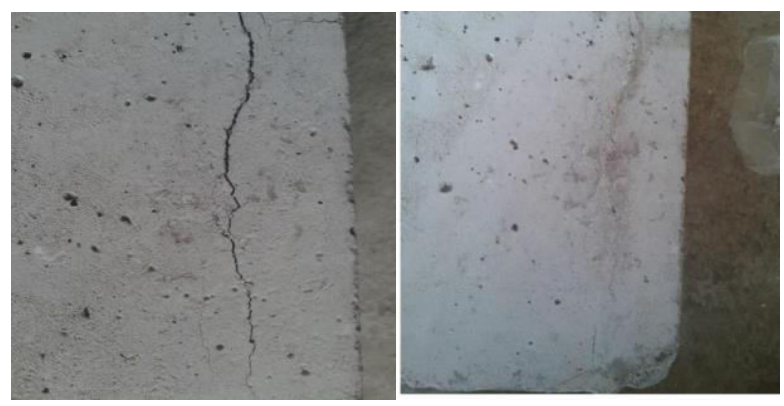

Figure 5 (a) Concrete cube- Before healing (b) Concrete cube- After healing

\section{CONCLUSION}

Based on experimental investigation carried out, following conclusions are drawn.

- Bacillus subtilis which is produced from the lab is proved to be safe and cost economical.

- The bacterium has potential to contribute to self healing capacity of concrete. We have shown that the bacteria incorporated has considerably filled the cracks present in the concrete and it is also found that there is an increase of $36.3 \%$ in compressive strength when compared to conventional cubes.

- The use of this biological repair technique is highly desirable because the mineral precipitation induced, as a result of microbial activities is pollution free and natural, however further experiments have to be done to examine the durability properties such as acid resistance, permeability.

- There is an increase of $29.2 \%$ of flexural strength and $45.3 \%$ of split tensile strength than the conventional controlled mix.

- As the percentage of addition of bacteria increases, the strength of the steel slag concrete also increases.

- From the above it can be concluded that the Bacillus subtilis can be easily cultured and safely used in improving the performance characteristics of concrete and self healing of cracks can be made.

\section{REFERENCES}

[1] A M al-Swaidani, R Ismat, M E Diyaband S D Aliyan, "Prediction of Corrosion Resistance of Concrete Containing Natural Pozzolan from Compressive Strength", IOP Conf. Series: Materials Science and Engineering 96 (2015) 012007.

[2] Zarina Itam1, SalmiaBeddu, NurLiyanaMohd Kamal, MdAshrafulAlam,, UsamaIssaAyash, "The Feasibility of Palm Kernel Shell as a Replacement for Coarse Aggregate in Lightweight Concrete", IOP Conf. Series: Earth and Environmental Science 32 (2016) 012040.

[3] MazizahEzdianiMohamad, Ali A. Mahmood, Alicia Yik Yee Min, NurHafizah A. Khalid, "A Review of the Mechanical Properties of Concrete Containing Biofillers", IOP Conf. Series: Materials Science and Engineering 160 (2016) 012064. 
[4] Marshall Stoneham, "How soft materials control harder ones: routes to bioorganization", 2007 Rep. Prog. Phys. 701055

[5] D Palin, V Wiktor and H M Jonkers, "A bacteria based bead for possible self healing marine concrete applications", 2016 Smart Mater. Struct. 25084008.

[6] A Kanellopoulos, P Giannaros, D Palmer, A Kerr and A Al-Tabbaa, "Polymeric microcapsules with switchable mechanical properties for self-healing concrete: synthesis, characterisation and proof of concept", Smart Mater. Struct. 26 (2017) 045025.

[7] V Wiktor and H M Jonkers, "Bacteria-based concrete: from concept to market", Smart Materials and Structures, 25 (2016) 8.

[8] Pappupreethi K, RajishaVelluvaAmmakunnoth, P. Magudeaswaran, "Bacterial concrete: A review, International Journal of Civil Engineering and Technology", 8 (2017) 2, 588-594

[9] Abhishek Thakur, AkshayPhogat, Khushpreet Singh, "Bacterial concrete and effect of different bacteria on the strength and water absorption characteristics of concrete: A review", International Journal of Civil Engineering and Technology, 7 (2016) 5, 43-56.

[10] SalmabanuLuhar, SutharGourav, "A Review Paper on Self Healing Concrete", Journal of Civil Engineering Research 5 (2015) 3, 53-58.
[11] MounaBouassida, "Potential application of Bacillus subtilis SPB1 lipopeptides in toothpaste formulation", Journal of Advanced Research 8 (2017) 425-433.

[12] Nguyen Ngoc Tri Huynh, "Bacillus subtilis HU58 immobilized in micropores of diatomite for using in self-healing concrete". Procedia Engineering 171 ( 2017 ) $598-605$.

[13] WoutKnoben, "Bacteria care for concrete", Holst Centre, The Netherlands,444 (2011),14(9)

[14] VirginieWiktor, "Quantification of crack-healing in novel bacteriabased self-healing concrete", Cement \& Concrete Composites, 33 (2011) 763-770.

[15] Vimala P. P, Lea Mathew, "Biodegradation of Polyethylene using Bacillus subtilis", Procedia Technology 24 ( 2016 ) 232 -239,

[16] Marie Lefevre, "Safety assessment of Bacillus subtilis CU1 for use as a probiotic in Humans", Regulatory Toxicology and Pharmacology 83(2017) 54-65.

[17] S.Soundharya, K.Nirmalkumar, "Study on the Effect of CalcitePrecipitating Bacteria on Self-Healing Mechanism of Concrete Review Paper", International Journal Of Engineering Research \& Management Technology, 1(2014) 4, 202- 207. 